\title{
Ukraine and Temporary Migration in the European-Asian Transnational Space
}

Ihor Markov, Svitlana Odynets, Danylo Sudyn

Part of the International Perspectives on Migration book series (IPMI, volume 14)

\section{Abstract}

This chapter is focused on the placing of Ukraine in temporary transnational migration in EuroAsian social space. For different categories of migrants Ukraine is a country to be used for further movement. Highly skilled specialists come to Ukraine, stay for several years and try to migrate to other countries; unskilled workers or asylum seekers are mostly transit migrants looking for possibilities to continue their trans-border movement to West. On the other hand, Ukrainian outmigrants to the EU and Asian countries intend to return home, but are not sure when it is actually going to happen. Sometimes they move from one country or region to another in order to find appropriate life and working conditions. Many of return migrants stay at home for some time and then, lacking adequate employment in the home country go abroad again using migrants' networks. It means that for many Ukrainian external migrants the return home is only one of the stages in realizing their migration projects. Our findings reveal that temporary migration becomes a permanent way of life for various categories of people. Therefore, the temporariness of migration turns to be a phenomenon of constructing the social relations of the "people on move": they are not willing to fully integrate into host societies (e.g. learning language etc.). Main politico-legal, socioeconomic and socio-cultural aspects of external migration in Ukraine (involvement of officials in the corrupt schemes providing necessary permits to stay in Ukraine and transit through its territory to the EU, migrants' remittances becoming means of mobilization for non-migrants, relative adaptation of migrants not by official Ukrainian institutions but rather through social and illegal transnational networks) put the country at the crossroad of transnational migrants' networks and flows.

\section{Keywords}

\section{Migratory movements Temporariness of migration Transit country Corrupt schemes Transnational networks}

\section{References}

1. Benson, M., \& O'Reilly, K. (Eds.). (2009). Lifestyle migration. Expectations, aspirations and experiences. Aldershot: Ashgate.Google Scholar

2. Brednikova, O., \& Tkach, O. (2010). What home means to the nomad. Laboratorium, 3, 72-95.Google $\underline{\text { Scholar }}$

3. Chorniy, P., Hodovanska, O., Markov, I., Odynets, S., Sudyn, D., Trofimova, A., \& Zaremba G. (2014). Flows and patterns of temporary migration: Country report from Ukraine. In P. Pitkänen and M. Korpela (Eds.), Characteristics of temporary transnational migration, Collected Working Papers from the EURA-NET project, 345-393. Retrieved from: http://www.uta.fi/edu/en/research/projects/euranet/publications/Characteristics\%20of\%20Temporary\%20Transnational\%20Migration EURA-NET.pdf

4. Dorosh, S. (2016). Why Ukraine denies political refugees from Russia (2016), BBC Ukraine. Retrieved from: http://www.bbc.com/ukrainian/politics/2016/02/160208 asylum seekers russia ukraine sd

5. Duvell, F., \& Vollner, B. (2009). Irregular migration in and from the neighborhood of the EU. A comparison of Morocco, Turkey and Ukraine. Clandestino: Undocumented migration counting the uncountible. Data and Trends across Europe. Retrieved 
from: http://www.hwwi.org/typo3 upload/groups/31/4.Background Information/4.6.Link library Internal Documents/Transit report COMPAS Sept09.pdf

6. Hugo, G. (2013). What we know about circular migration and enhanced mobility. Retrieved from: file://C:/Users/ADM/Downloads/Circular-Migration\%20(2).pdfGoogle Scholar

7. IOM Ukraine. (2016). The migration in Ukraine. Facts and figures. A study on the nexus between development and migration-related financial flows to Ukraine. Retrieved

from: http://www.iom.org.ua/sites/default/files/iom migration as an enabler of development in ukrai $\underline{\text { ne.pdf }}$

8. Libanova, E. (2013) Report on Methodology, Organization and Results of Module Sampling Research on Labour Migration in Ukraine. International Labour Organization. Technical Support Group for Decent Work and ILO Bureau for Eastern and Central Europe. Budapest, ILO.Google Scholar

9. Libanova, E. (Ed.). (2015). The policy of integration of Ukrainian Society in the context of challenges and threats of the Donbas events. The National Report. Kiev: National Academy of Sciences of Ukraine.Google $\underline{\text { Scholar }}$

10. Libanova, E., Pozniak, O., \& Malynovska, O. (Eds.). (2010). Emigration. Population of Ukraine. Labour emigration in Ukraine. Kyiv: M. Ptukha Institute for Demography and Social Studies of the National Academy of Sciences of Ukraine. 2010. Retrieved from: http://www.idss.org.ua/monografii/poznyak 2010.pdf.

11. Malynovska, O. (2016). Tasks of migration policy of Ukraine in the context of visa dialog with EU. Retrieved from: http://novisa.org.ua/upload/file/MalynovskaMigrationPolicyENG.pdf

12. Markov, I. (Ed.). (2009). At the crossroads. Findings of the complex research of the processes of Ukrainian labour migration: The EU countries and Russian Federation. Lviv: Papuha.Google Scholar

13. Markov, I. (2015). Globalization and migrations: Theoretical and methodological aspects of studies on sociodynamics. Ethnological Papers (Narodoznavchi zoshyty), 6(126), 1320-1330.Google Scholar

14. Markov, I. (2016). Contemporary Ukrainian migration to EU countries: Trends and challenges. In I. Liikanen, J. Scott, \& T. Sotkasiira (Eds.), Migration, borders and regional stability in the EU's Eastern neighbourhood (pp. 247-256). London: Routledge.Google Scholar

15. Ministry of Foreign Affairs of Ukraine (2016). Statistical data. Retrieved from: http://www.nrcu.gov.ua/en/news.html?newsID=27121

16. Odynets, S. (2015). Ukrainianness in action: Representation of identities with ethnic and national dominants in transnational communities of Ukrainian migrant women in Italy. Ethnological Papers (Narodoznavchi zoshyty), 6(126), 1435-1445.Google Scholar

17. Peshko, K. (2016). Ella Libanova: Ukraine is experiencing a new wave of brain drain, Glavcom, available at: http://glavcom.ua/interviews/133633-ella-libanova-ukrajina-perezhivaje-novu-hvilju-vidtoku-mizkiv

18. Pries, L. (1999). Migration and transnational social spaces. Aldershot: Ashgate.Google Scholar

19. Regulation on the prolongation of duration of stay and prolongation or reduction of term of temporary stay of the foreigners and persons destitute of nationality at the territory of Ukraine. Approved by the regulation of the Cabinet of Ministers of Ukraine. February 15, 2012. № 150. Retrieved from: http://zakon4.rada.gov.ua/laws/show/150-2012-\%D0\%BF

20. The Ministry of Foreign Affairs. (2016). "Almost 5 million Ukrainians living legally abroad" Ukrainian Radio (Ukrajinske Radio). Retrieved from: http://www.nrcu.gov.ua/en/news.html?newsID=27121 
21. The United Nations High Commissioner for Refugees. (2016). Report on the Human Rights Situation in Ukraine 16 February to 15 May 2016. Retrieved

from: http://www.ohchr.org/Documents/Countries/UA/Ukraine 14th HRMMU Report.pdf

22. Ukraine Migration Profile 2010-2014. (2015). State migration service of Ukraine. Retrieved from: http://dmsu.gov.ua/images/files/profile 2015 en.pdf 